\title{
DETERMINATION OF INTERNET BANKING CUSTOMER SATISFACTION - STUDY AT SOE'S BANK IN INDONESIA
}

\author{
Imaduddin Murdifin, Munawir Nasir, Muhammad Ashoer, \\ Muh. Haerdiansyah Syahnur* \\ Universitas Muslim Indonesia
}

\begin{abstract}
This study seeks to identify the role of perception of information technology, service quality, and trust on customer satisfaction of internet banking users in several State-Owned Enterprises (SOE) Banks in Indonesia. The study involved 228 respondents from BBRI, BMRI, and BBNI. The stages in data analysis involve the classical assumption, validity \& reliability, and effect test using PLS-SEM. The results accept all hypotheses with positive and significant effects. This study finds that the optimal use and application of information technology systems can increase perceptions of internet banking use on customer satisfaction at SOE banks in Indonesia.
\end{abstract}

Keywords: Perceptions of Information Technology; Service Quality; Trust; Satisfaction, Structural Equation Modelling

Submitted: 15 April 2021; Revised: 2, 7, E 9 June 2021; Accepted: 15 June 2021

*Corresponding Author : haerdiansyah@umi.ac.id

DOI: $10.24252 /$ minds.v8i1.20640

ISSN-E: 2597-6990

ISSN-P: 2442-4951

http://journal.uin-alauddin.ac.id/index.php/minds

Publisher: Program Studi Manajemen, Universitas Islam Negeri Alauddin Makassar 


\section{INTRODUCTION}

This research is related to the behavior of internet users in Indonesia who carry out banking transactions, such as online selling, online shopping, online transfers, and trading, which are still not fully utilized. The banking sector is one of the service industries that can encourage Indonesia's economic growth. The bank also has a strategic role in national economic development. As a financial services institution, one of the fundamental roles of banks is channeling funds to people who need business capital either through micro-enterprises, small businesses, or medium businesses (Fahrial, 2018). The objectiveness of this study discusses the role of perceptions of information technology, service quality, and trust on customer satisfaction of internet banking users from State-Owned Enterprises (SOE) Banks in Indonesia. Like internet banking transactions of several large banks, electronic banking increases, showing that customers prefer non-cash transactions. PT Bank Negara Indonesia Tbk (BBNI) recorded around 2 million active internet banking users, Bank Mandiri Tbk (BMRI) recorded approximately 8.8 million registered as mobile \& internet banking users. At the same time, PT Bank Rakyat Indonesia Tbk (BBRI) had internet banking users of 15.46 million members. Otherwise, PT Bank Central Asia Tbk (BBCA) with BCA internet banking records 150 million memberships (Hutauruk \& Laoli Noverius, 2019). The growth of customers is dominated by private banking, Bank Central Asia (BBCA), which according to (Sharingvision, 2015) is based on user data from 6 major banks in Indonesia. In 2016, the total number of Internet Banking users reached Rp. 5.617 trillion. Bank BCA controls almost the entire value of Internet Banking transactions with a total of Rp. 5.349 trillion. The development of information technology has made banks change their business strategy by placing technology as a significant element in product and service innovation. In recent years, commercial banks have introduced internet-based banking systems to improve operations and reduce costs. Banking transactions that were initially carried out conventionally, nowadays with the development of the internet can be presented as the primary medium to facilitate transactions with customers. Initially, customers who were going to make transactions had to come to the nearest bank office to carry out their activities, but now it has become easier because banks have used internet-based technology that can be accessed either via netbooks or mobile devices.

This study examines the concept of service quality as one of the variables that directly affect customer satisfaction or not. Based on these considerations, the researchers put forward several theories and concepts related to service quality. (Kotler \& Keller, 2012) states that services are intangible, inseparable, varied, and perishable products, so services usually require quality control, supplier credibility, and greater adaptability. The quality of a product or service needs to be determined through its dimensions. According to (Lovelock et al., 2007) argues that (Zeithaml \& Bitner, 2008) conducted intensive research on service quality and identified ten dimensions used by consumers in evaluating service quality. In subsequent studies, they found a high correlation between 
several variables and finally consolidated it into five broad dimensions. The dimensions meant are Tangibles - the appearance of physical elements; Reliability - reliable and accurate performance; Responsiveness - speed and Usability credibility, security, competence, and politeness; and Empathy - easy access, good communication, and customer understanding.

Customer satisfaction is a response to meeting customer needs. Satisfaction is assessing the characteristics or features of a product or service or the product itself, which provides a level of consumer pleasure related to meeting consumer needs. (Kotler \& Lee, 2009) satisfaction is a feeling of contentment or disappointment for someone that arises because of comparing the product's perceived performance or results against their expectations. If performance fails to meet expectations, customers will be dissatisfied. If the performance is as expected, the customer will be satisfied. If the performance exceeds expectations, the customer will be very satisfied or happy. (Syahnur et al., 2018) Every company can see the importance of customer satisfaction by conducting an assessment based on the Customer Satisfaction Index in the face of increasingly stringent business developments. CSI is used to analyze customer satisfaction by looking at the importance of product or service attributes. Because, according to (Tjiptono \& Chandra., 2011) the creation of customer satisfaction can provide several benefits, including the relationship between businesses and customers into a harmonious, offer a good foundation for the repurchase and the design of customer loyalty, as well as form a recommendation by word of mouth (WoM) that benefit the company.

Based on the phenomenon described, there is a significant number of transactions between internet banking customers of State-Owned Enterprises (SOE) Banks in Indonesia (BBNI, BBRI, BMRI) compared to private banks (BBCA). In addition, the use of information and telecommunications systems has also become a new phenomenon in the banking world in presenting superior features to facilitate customers in conducting transactions. The security system guarantees customers' trust every time they make a transaction is an important thing that cannot be ruled out. This research is expected to reveal the role of customers in conducting transactions using internet banking. The gap emerges from previous studies that there has been no research that raises comparisons between State-Owned Enterprises (SOE) Banks in Indonesia(BBNI, BBRI, BMRI) and private banks (BBCA) in Indonesia. The novelty of the research is also shown from the use of respondents consisting of customers of three large State-Owned Enterprises (SOE) Banks in Indonesia that exist in Indonesia, but in terms of the number of transactions, it is still far from internet banking transactions made by private bank (BBCA) customers.

\section{THEORETICAL REVIEW}

\section{Perception of Information Technology}

Perceptions of information technology are defined as the degree to which someone believes that using information technology can make work shorter than people who do not use information technology (Davis et al., 1989; Amijaya, 2010). 
There are various information technology acceptance models used to measure the acceptance of an information system. One of the models that are often used is the Technology Acceptance Model (TAM). TAM, introduced by (Davis et al., 1989), is an adaptation of the Theory of Reasoned Action (TRA) designed explicitly for modeling user acceptance of information systems. The TAM aims to support general computation-based acceptance factors, which allow it to explain the behavior of end-users of computing technology while simultaneously saving time. The TAM model is influenced by two beliefs: user perceptions of perceived usefulness and user perceptions of ease-perceived ease of use. Perceived usefulness is defined as the degree to which a person believes that using a particular system can improve performance. Customer desires are needs that are shaped by the culture and personality of the individual itself. In the banking industry, the needs of bank customers are a condition that is felt in a person, where among them is a sense of security when dealing with the bank (Kasmir, 2014). According to (Ribbink et al., 2004), they want to get quality-satisfactory service, get fast service, and security from every transaction. Perception of information technology for each customer is one of the important reasons for consumer acceptance of the implementation of internet services in the banking world in Indonesia.

According to (Pratomo, 2017), the perception of ease of use of information technology has no significant effect on customer satisfaction. Also, this study shows that the perceived ease of use of information technology is proven to have no and insignificant impact on customer loyalty, and service quality is proven to have a significant and significant effect on customer satisfaction. (Amijaya, 2010); (Soelistya \& Agustina, 2017) revealed that the perception of information technology affects the interest in reuse by internet banking customers. Research related to Perceptions of Information Technology and Customer Satisfaction was also carried out by (Soelistya \& Agustina, 2017), showing that the partial test between variables shows that the perception variable on technology partially has a significant effect on customer satisfaction. Research (Pratomo, 2017) contradicts the results of research by (Amijaya, 2010) and (Soelistya \& Agustina, 2017), where this study discusses the effect of perceptions of information technology on internet customers satisfaction banking, several possible variables are expected to affect customer satisfaction. Based on the explanation above, a hypothesis is formed.

H1: Perception of Information and Technology has a positive significant direct effect on Customer Satisfaction.

\section{Service Quality}

Conceptually, service quality is defined as a global decision or attitude related to all the advantages or superiority of service (Parasuraman, 1997), which reveals service quality measurement using a 10-dimensional instrument consisting of 97 question items. The ten dimensions are tangibles, reliability, responsiveness, communication, credibility, security, competence, courtesy, understanding, or knowing the customer and access. Further research (Parasuraman et al., 2012) succeeded in summarizing the 10-dimensional model into a 5-dimensional model with 22 question items, consisting of tangibles, 
reliability, responsiveness, assurance, and empathy. According to (Wijaya \& Wismantoro, 2017), product quality has a positive and significant effect on customer trust and satisfaction. Other research related to internet banking customers, conducted by (Yuliaty, 2014) shows that there is an effect of internet banking service quality on customer satisfaction, but it is not significant. Based on the explanation above, a hypothesis is formed, namely:

H2: Services Quality has a positive significant direct effect on Customer Satisfaction.

\section{Customer Trust}

Customer trust is a type of emotional reflection for trading. This function depends on the level of fulfillment of the expected product or service benefits, as well as the level of consistency of expectations and actual results if the customer expects a certain level of service and feels that the service received is higher than what he expected and continues to use the product or service (Tjiptono \& Chandra., 2011). Given that the banking industry is a business of trust, customer trust should also concern banking service providers. (Farizi \& Syaefullah, 2013) stated that trust influences the interest in using internet banking. The trust factor is a factor that influences the acceptance of internet banking, so that banks must form a positive attitude that can increase customer confidence in the technology applied. The hypothesis is proposed, and figure 1 depicts the proposed conceptual framework.

H3: Trust has a positive significant direct effect on Customer Satisfaction.

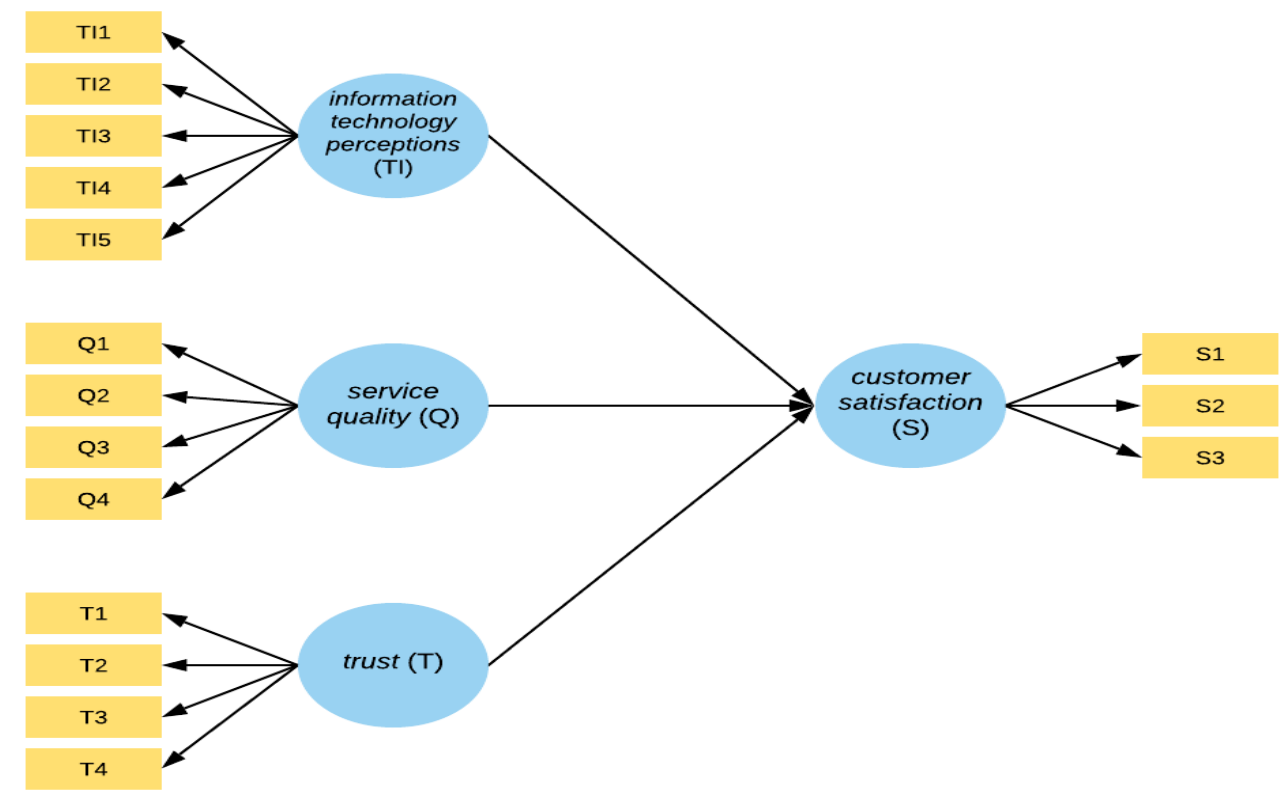

Figure 1 Conceptual Framework 


\section{METHODOLOGY}

\section{Sample Criteria}

This study used two research methods: exploratory research (exploratory research) and descriptive research. The minimum number of research samples is required to meet the standards and requirements for Structural Equation Modeling variant-based (SEM) analysis, which is 5-10 times the number of statement items tested (Hair et al., 2007). The minimum number of respondents needed to process the data in this study is $16 \times 5=80$ respondents. As a result, the total number of respondents who participated in the survey online was 235 people. However, after going through a sample screening process (judgment), internet banking users of Banks in Indonesia State-Owned Enterprises (SOE)customers who met the requirements were set at 228 from various educational backgrounds (i.e., bachelor or master). All research samples are users who have used application mobile and internet banking at least once a month. The sampling method used was an online survey with variable measurement coding using a Likert scale 1 - 5 ( 1 = Strongly Disagree until $5=$ Strongly agree $)$ with purposive random sampling mode.

\section{Measurement}

Data testing in this study was carried out in several stages, namely:

1. Evaluation of the outer model, also known as the evaluation of the measurement model, was carried out to assess the validity and reliability of the model. The measurement model with reflexive indicators is evaluated by convergent and discriminant validity for scale formation of latent constructs and composite reliability and Cronbach alpha for the indicator items (Ghozali, 2011). The convergent validity test of reflexive indicators can be seen from following criteria:

$\begin{array}{ll}\text { Loading Factor } & >0,70 \\ \text { AVE (Average variance extracted) } & >0,50 \\ \text { Composite Reliability }>0,60 & \\ \text { Cronbach's Alpha }>0,70 & \end{array}$

The PLS structural model can be seen from the R-Square value for each endogenous latent variable as the predictive ability of the structural model with $\mathrm{R}^{2} \geq 0,67$ indicates a robust model, 0,33 indicates a moderate model, and $\leq 0,19$ suggests a weak model.

2. Three primary constructs: measure variable Perception of Information and Technology, Service Quality, and trust, are illustrated in Table 1. Perception of Information and Technology measured by five items measurements, Service Quality and Trust measured by four things, and three items measured Customer Satisfaction. 
Table 1 Measurement Table

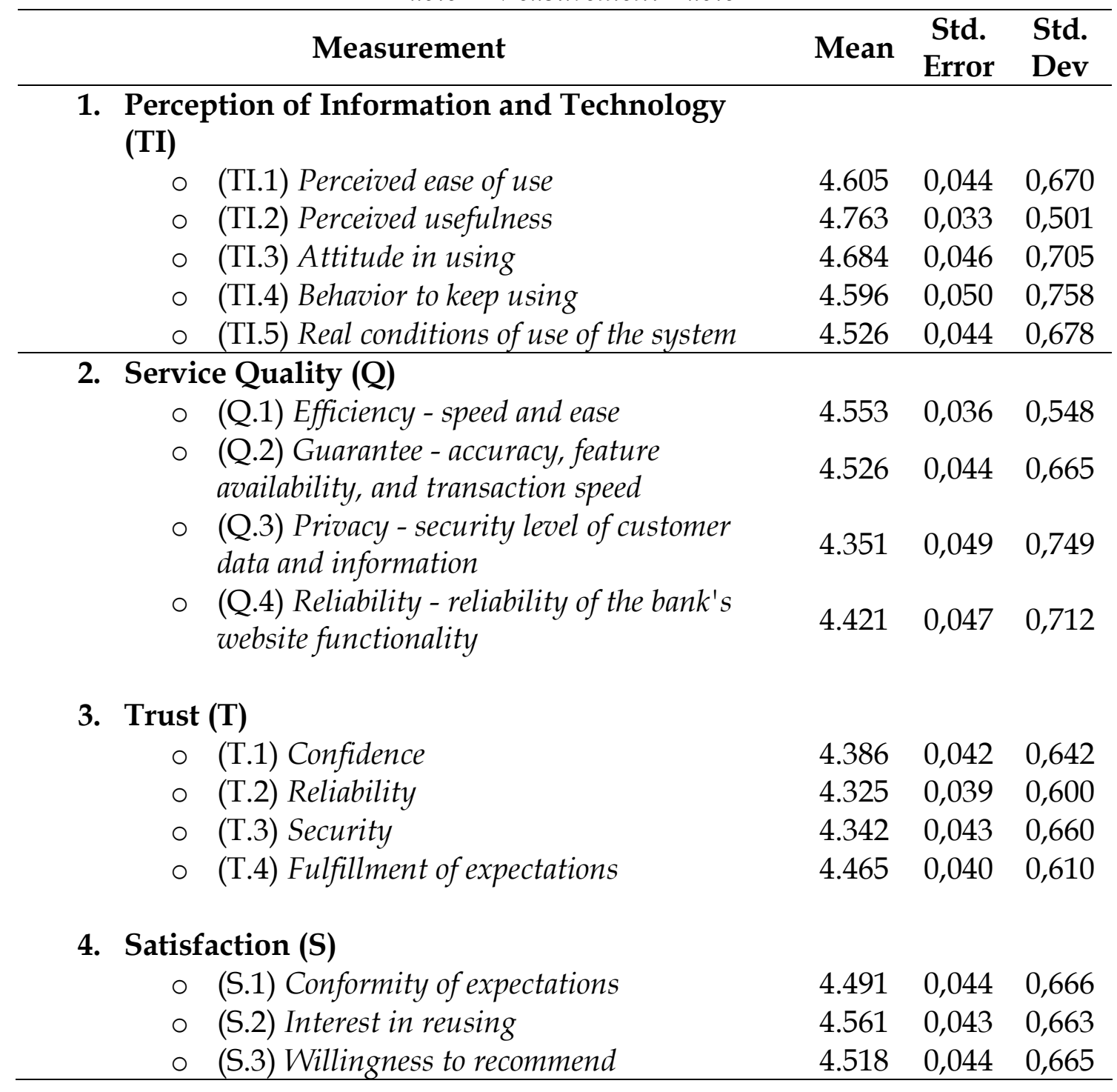

Therefore, in investigating the symmetrical path configurations, the data analysis methods used are regression and correlation analysis. This study's testing phase is through three stages: first, the validity and reliability of the constructs. Second, the relationship that explains the direct effects of Perception of Information and Technology, Service Quality, Trust and Satisfaction; and third, the relationship that demonstrates the impact of all variables that measured

\section{RESULT}

As we can see from table 2 below, statistical analysis testing shows that testing the feasibility of the model is declared valid and reliable. The most dominant indicator of the Perception of Information and Technology (TI) construct is formed by; (TI.4 a = 0.8361). Overall reliable Perception of Information and Technology (TI) manifest items form a constructed variable of 0,894. Second, The most dominant indicator of the Service Quality (Q) construct 
is formed by; (Q.2 a = 0.806) Overall reliable Service Quality $(Q)$ manifest items form a constructed variable of 0,859 . Third, The most dominant indicator of the Trust (T) construct is formed by; (T.1 \& T.4 a $=0.892)$ Overall reliable Trust (T) manifest items form a constructed variable of 0,936. Fourth, The most dominant indicator of the Satisfaction (S) construct is formed by; (S.3 a $=0,917)$ Overall reliable Satisfaction (S) manifest items form a constructed variable of 0,930.

Table 2 Statistical Analysis Table

\begin{tabular}{|c|c|c|c|c|c|c|}
\hline Measurement & Loading & AVE & CR & Alpha & \multicolumn{2}{|c|}{ Result } \\
\hline \multicolumn{7}{|l|}{$\begin{array}{l}\text { Perception of } \\
\text { Information and } \\
\text { Technology (TI) }\end{array}$} \\
\hline $\begin{array}{ll}\circ \mathrm{TI} .1 \\
\mathrm{l}\end{array}$ & 0,752 & \multirow{5}{*}{0.629} & \multirow{5}{*}{0,894} & \multirow{5}{*}{0,853} & \multirow{5}{*}{\multicolumn{2}{|c|}{ Valid \& Reliable }} \\
\hline ○ TI.2 & 0,760 & & & & & \\
\hline ○ TI.3 & 0,807 & & & & & \\
\hline ○ $\mathrm{TI} .4$ & 0,836 & & & & & \\
\hline ○ TI.5 & 0,808 & & & & & \\
\hline \multicolumn{7}{|l|}{ 2. Service Quality (Q) } \\
\hline$\circ$ Q.1 & 0,793 & \multirow{4}{*}{0,604} & \multirow{4}{*}{0,859} & \multirow{4}{*}{0,782} & \multirow{4}{*}{\multicolumn{2}{|c|}{ Valid \& Reliable }} \\
\hline ○ Q.2 & 0,806 & & & & & \\
\hline ○ Q. Q.3 & 0,743 & & & & & \\
\hline$\circ \quad \mathrm{Q} .4$ & 0,767 & & & & & \\
\hline \multicolumn{7}{|l|}{ 3. $\quad$ Trust $(\mathrm{T})$} \\
\hline ○ T.1 & 0,892 & \multirow{4}{*}{0,784} & \multirow{4}{*}{0,936} & \multirow{4}{*}{0,908} & \multirow{4}{*}{\multicolumn{2}{|c|}{ Valid \& Reliable }} \\
\hline ○ $\quad \mathrm{T} .2$ & 0,872 & & & & & \\
\hline ○ $\quad$ T.3 & 0,887 & & & & & \\
\hline$\circ \mathrm{T} .4$ & 0,892 & & & & & \\
\hline \multicolumn{7}{|l|}{ 4. Satisfaction (S) } \\
\hline ○ $\quad$ S.1 & 0,886 & \multirow{3}{*}{0,817} & \multirow{3}{*}{0,930} & \multirow{3}{*}{0,888} & \multirow{3}{*}{\multicolumn{2}{|c|}{ Valid \& Reliable }} \\
\hline ○ $\quad$ S.2 & 0,908 & & & & & \\
\hline$\circ \quad S .3$ & 0,917 & & & & & \\
\hline \multicolumn{7}{|c|}{$\begin{array}{c}\text { Normality Test } \\
\text { Kolmogorov-Smirnov } Z=0,541 \\
\text { Asymp Sig }=0,931\end{array}$} \\
\hline \multicolumn{7}{|c|}{ Hypothesis Test } \\
\hline Direct Test & $\begin{array}{l}\text { Original } \\
\text { Sample } \\
\text { (O) }\end{array}$ & $\begin{array}{c}\text { Sample } \\
\text { Mean (M) }\end{array}$ & STDEV & $\begin{array}{l}\text { T Statistics } \\
\text { (|O/STDE } \\
\text { V|) }\end{array}$ & $\begin{array}{c}\mathbf{P} \\
\text { Values }\end{array}$ & Sign. \\
\hline $\begin{array}{c}\text { Perception of Information and } \\
\text { Technology (TI) } \rightarrow \text { Satisfaction } \\
\text { (S) }\end{array}$ & 0,304 & 0,299 & 0,054 & 5,581 & 0,000 & Sig. \\
\hline $\begin{array}{c}\text { Service Quality }(Q) \rightarrow \\
\text { Satisfaction }(S)\end{array}$ & 0,291 & 0,297 & 0,065 & 4,489 & 0,000 & Sig \\
\hline Trust $(\mathrm{T}) \rightarrow$ Satisfaction $(\mathrm{S})$ & 0,367 & 0,367 & 0,063 & 5,818 & 0,000 & Sig. \\
\hline Satisfaction (S) & & $\begin{array}{l}\text { R Test } \\
\text { R Square } \\
0,747\end{array}$ & & \multicolumn{3}{|c|}{$\begin{array}{c}\text { R Square Adjusted } \\
0,743\end{array}$} \\
\hline
\end{tabular}

Source: Primary Data (processed, 2020). 
From the three symmetrical paths, the direct relationships report significant results. The hypothesis tests found that all of the variables used in the model are positive and significant. The $\mathrm{T}$ table value obtained by looking at the 0.05 sign error with $n=228$ is 1.651564 , so it can be concluded that each measured variable can be stated as having a positive effect. The test results of the path coefficient also show that the Trust (T) has the most significant direct influence on Internet Banking User Customer Satisfaction (S), which is 5,818.

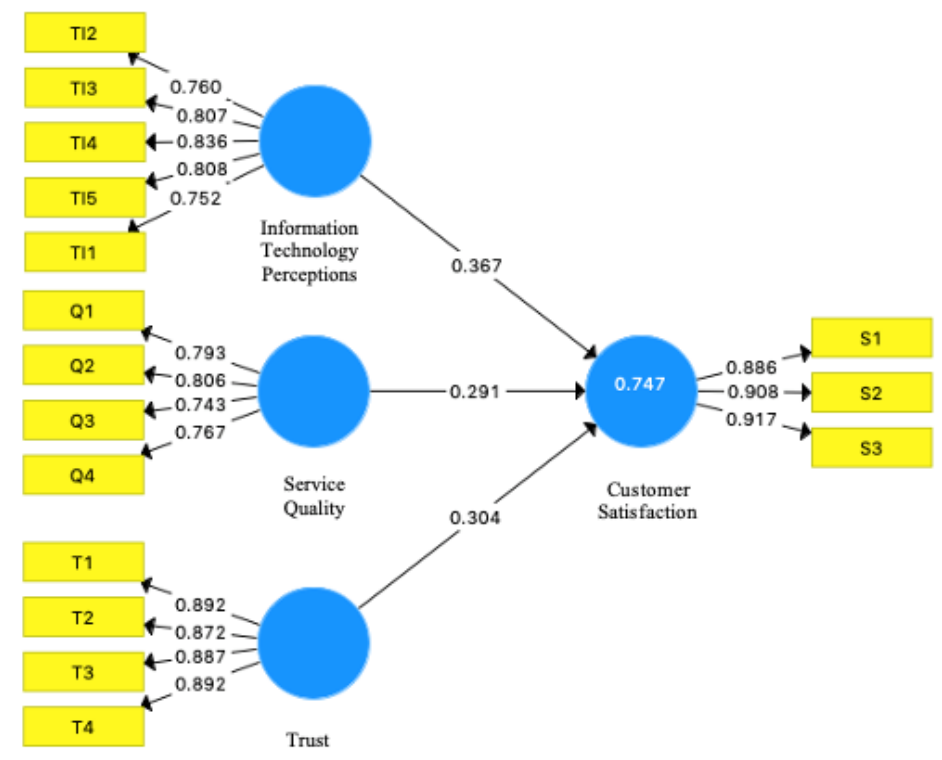

Figure 2 Analysis Result

\section{DISCUSSION}

This discussion is focused on decisions resulting from hypothesis testing to answer the formulation of research problems. The following describes the results of the analysis of statistical data processing using the PLS-SEM technique. Perception of Information Technology is defined as customer behavior and responses that arise because of objects to the products and services used. Empirical research shows that the perception of information technology has a positive and significant effect on satisfaction. The perception of information technology has a positive and significant impact on customer satisfaction of StateOwned Enterprises (SOE) Banks in Indonesia. The results showed that customers were satisfied with the internet banking facilities provided by the SOE bank. The variables that make the satisfaction are influenced by customer responses or perceptions formed on several indicators used. The essential purpose of providing internet banking facilities also supports customer satisfaction by stating that they can do transactions within 24 hours with the devices they have and the most supportive of customers' statements that mobile smartphones make all transaction activities easier to do. As proposed by (Kotler \& Keller, 2012), perception is the process by which customers select, organize, and translate information input to create a meaningful world picture. Perception depends not only on physical stimuli but also on the relationship of stimuli to the field 
surrounding it and the conditions in each customer. Robbins \& Judge (2015) argue that perception is an individual process of organizing and interpreting sensory impressions to understand their environment. Perception is important to organizations because people's behavior is based on their perception of what reality is, not reality itself. The concept of information technology perception is reinforced by (Davis et al., 1989) on (Amijaya, 2010), which defines it as the level where someone believes that using information technology can work shorter than people who do not use information technology.

The use of information technology provides many advantages for customers, such as ease of transaction. In addition, service greatly influences customer satisfaction in using internet banking because of wider availability. This fact impacts customer satisfaction in using internet banking in line with the results of research, which found that by conducting banking transactions using technology, time and effort becoming more effective and efficient. This perception shapes customer behavior from the perceived convenience, usefulness, attitude to continue, usage behavior, and actual conditions to continue using information technology that encourages customer satisfaction. The results of this study are in line with research conducted by (Amijaya, 2010) who stated that the variables of Information Technology Perception, Convenience, Risk, and Service Features affect customers' Re-interest in using Internet Banking. This finding is in line with (Ahmad \& Pambudi, 2014), which states that there is an effect of perceived usefulness, perceived convenience, security, and feature availability on re-interest in using internet banking significantly. Re-interest can be interpreted that the experience felt by customers makes them reuse the available facilities.

Service quality is defined as customer responses to services internet banking, which is defined as a measure of how well the level of internet banking services offered by banks can match customer expectations. Quality is the highest appreciation of service action. The service quality of internet banking has a positive and significant effect on customer satisfaction. Due to the positive mathematical coefficient, the increasing intensity of quality achievement of internet banking services will increase customer satisfaction as internet banking users. Customer satisfaction results from their experience after comparing the quality of internet banking services. Match expectations using services with various features, ease of 24-hour transactions, the flexibility offered, and guarantee of efficient and safe transaction completion. Interest in reusing Internet Banking facilities and willingness to recommend and suggest experiences to friends, family, or people they meet. Customers can encourage others to use internet banking services because the benefits, convenience, security, and guarantee of transaction completion are satisfactory.

This research is in line with the theory and concept of service quality following the approach of "Quality" put forward by (Marcel, 2003) that the success of an act of marketing products and services is determined by quality. Quality is the highest appreciation of service action. There are five considerations for a company to implement service quality: maintaining the company's existence from customers, ensuring continuity of marketing activities, realizing 
customer satisfaction, fostering customer trust and image, and fostering customer loyalty. While (Kotler \& Lee, 2009) states that the services (services) are a product that is intangible, inseparable, variable, and can be destroyed so that the services usually require quality control, supplier credibility, and greater adaptability. Service quality contributes to constructs that shape customer satisfaction as internet banking users; as Parasuraman (1997) stated, the quality of service is determined by the company's ability to meet customer needs and desires following customer expectations. In other words, the main factor affecting service quality is expected service. The findings of this study are in line with the findings of (Khan \& Mahapatra, 2009), who evaluated the quality of internet banking (i-banking) services in India from a customer perspective. The results showed that customers were satisfied with service quality on four dimensions: reliability, accessibility, privacy/security, responsiveness, and compliance. Likewise, Utami (2015) states that the fulfillment of electronic service quality is the strongest predictor of electronic satisfaction.

Trust is defined as customer confidence in the operation of internet-based banking transactions and trust in the operational mechanism of the transactions made. Trust is several specific beliefs about the integrity of the trusted party and the ability to keep promises. Empirical research shows that trust has a positive and significant effect on satisfaction. Trust has a positive and significant impact on satisfaction. The increasing intensity of customer trust in using internet banking will allow customer satisfaction to increase. The concept of customer trust by (Mayer et al., 1995) defines trust as the willingness of one party to accept risks from the actions of the other party based on the expectation that the other party will take necessary measures for those who trust them, regardless of the ability to supervise and control the actions of the trusted party. Parasuraman et al. (2012) also echoed the understanding of trust, who view that customers must trust the company, customers will feel safe in making transactions with the company, and the transactions carried out will be guaranteed with trust certainty.

Trust in the internet banking facilities at state banks in Indonesia has been fulfilled by customer willingness to make transactions again. Banking is a trusted industry as far as possible to provide electronic-based services for smooth transactions that customers will carry out. Internet banking is an activity that conducts transactions, payments, and other transactions via the internet with a bank-owned website equipped with a security system so that customers will increase their efficiency, effectiveness, and productivity in transactions. On the other hand, banks provide digital-based services via internet banking. This service concept prioritizes effectiveness and efficiency so that Internet banking is one of the services that allows customers to obtain information, conduct transactions, and communicate with banks through the internet network. Education for customers needs to be intensified to increase trust in the security of using internet banking. Lau \& Lee (1999) defines trust as people willing to depend on other parties at risk. Trust is defined as the desire to rely on trusted exchange partners (Setiawan et al., 2016). This study points to that empathy as the highest positive customer satisfaction, and trust shows the most positive 
correlation with customer satisfaction. The same thing was stated by (Soegoto, 2013); (Syahnur et al., 2020) that trust partially has a significant effect on customer satisfaction. Meanwhile (Farizi \& Syaefullah, 2013) states that trust affects the interest in using internet banking. The trust factor is a factor that influences the acceptance of internet banking that banks are forming a positive attitude to increase customer confidence in the applied technology. Soegoto (2013) found that partially perceived value and trust significantly affect consumer satisfaction, partially perceived value, trust, and satisfaction significantly affect

\section{CONCLUSION}

Perception of information technology, service quality, and trust in this study proved to positively influence consumer satisfaction of Internet banking users of State-Owned Enterprises (SOE) Banks in Indonesia, either simultaneously or partially. This study shows that these variables need to be considered to continue to play a role in increasing customer satisfaction to support the performance and progress of banking companies in providing internet banking services. In addition, the commitment of the company's management and related partners is needed to provide quality internet banking facilities. For this reason, support from cellular operator-associated companies and partners is necessary so that the provision of infrastructure to access internet banking can be maximized. In increasing customer trust to use internet banking, a strong commitment from all company management is needed to build customer trust-security guarantees the use of internet banking facilities. Continuous education directly or through the media can be carried out so that consumers who transact using internet media can be done better and more efficiently, any time for 24 hours. In comparison, this research was only conducted on internet banking consumers using State-Owned Enterprises (SOE) Banks in Indonesia. So that the results, conclusions, or suggestions given do not reflect the general effects of other internet banking users. Periodic and structured testing is needed on every other research object to get a more reliable result.

\section{REFERENCES}

Ahmad, \& Pambudi, B. S. (2014). Pengaruh Persepsi Manfaat, Persepsi Kemudahan, Keamanan Dan Ketersediaan Fitur Terhadap Minat Ulang Nasabah Bank Dalam Menggunakan Internet Banking (Studi Pada Program Layanan Internet Banking BRI). Journal of Management Studies, 8(1), 1-11.

Amijaya, G. R. (2010). Pengaruh Persepsi Teknologi Informasi, Kemudahan, Resiko Dan Fitur Layanan Terhadap Minat Ulang Nasabah Bank Dalam Menggunakan Internet Banking (Studi Pada Nasabah Bank BCA) [Universitas Dipanegoro]. http:/ / eprints.undip.ac.id/22558/1/GILANG_RIZKY_AMIJAYA.pdf

Davis, F. D., Bagozzi, R. P., \& Warshaw, P. R. (1989). User Acceptance Of Computer Technology: A Comparison Of Two Theoretical Models *. 35(8), 982-1003.

Fahrial, F. (2018). Peranan Bank dalam Pembangunan Ekonomi Nasional. Ensiklopedia of Journal, 1(1), 179-184. 
Farizi, H., \& Syaefullah. (2013). Pengaruh Persepsi Kegunaan, Persepsi Kemudahan, Persepsi Risiko Dan Kepercayaan Terhadap Minat Menggunakan Internet Banking. Jurnal Ilmiah Mahasiswa Fakultas Ekonomi Dan Bisnis, 1-18.

Ghozali, I. (2011). Aplikasi Analisis Multivariate Dengan Program SPSS. Universitas Diponegoro.

Hair, J. F., Money, A. H., Samouel, P., \& Page, M. (2007). Research methods for business. Education+ Training.

Hutauruk, D. M., \& Laoli Noverius. (2019, September 24). Transaksi mobile dan internet banking di sejumlah bank meningkat tajam - Page all. https:/ / keuangan.kontan.co.id/news/transaksi-mobile-dan-internetbanking-di-sejumlah-bank-meningkat-tajam?page=all

Kasmir. (2014). Bank dan Lembaga Keuangan Lainnya. PT Rajagrafindo Persada.

Khan, M. S., \& Mahapatra, S. S. (2009). Service quality evaluation in internet banking: an empirical study in India. International Journal of Indian Culture and Business Management, 2(1), 30-46.

Kotler, P., \& Keller, K. L. (2012). Marketing Management. Prentice Hall.

Kotler, P., \& Lee, N. R. (2009). Up and Out of Poverty: The Social Marketing Solution. Pearson Education, Inc.

Lau, G. T., \& Lee, S. H. (1999). Consumers' trust in a brand and the link to brand loyalty. Journal of Market-Focused Management, 4(4), 341-370.

Lovelock, C. H., Widyantoro, A., Samosir, M., \& Wright, L. K. (2007). Manajemen Pemasaran Jasa. Indeks.

Marcel, Davidson, 2003. Service Quality in Concept and Theory. Published by American Press, USA.

Mayer, R. C., Davis, J. H., \& Schoorman, F. D. (1995). An integrative model of organizational trust. Academy of Management Review, 20(3), 709-734.

Parasuraman, A. (1997). Reflections on Gaining Competitive Advantage Through Customer Value. 25(2), 154-161.

Parasuraman, A., Zeithaml, A., \& Berry, L. (2012). of Expectations as a Standard in Measuring Comparison Service for Quality: Implications Further Research. Journal of Marketing, 58(1), 111-124.

Pertumbuhan Internet Banking di Indonesia - SHARINGVISION. (2015). Anonim. https:// sharingvision.com/pertumbuhan-internet-banking-di-indonesia/

Pratomo, Z. P. (2017). Analisis Pengaruh Persepsi Kemudahan Penggunaan Teknologi Informasi Dan Kualitas Pelayanan Terhadap Loyalitas Nasabah Yang Dimediasi Oleh Kepuasan Nasabah Pada PT Bank Mandiri Cabang Jakarta R. P. SOEROSO [Universitas Mercubuana]. https:/ / repository.mercubuana.ac.id/38743/

Ribbink, D., Riel, A. C. R. Van, Liljander, V., \& Streukens, S. (2004). Comfort your online customer : quality, trust and loyalty on the internet. Managing Service Quality, 14(6), 446-456. https://doi.org/10.1108/09604520410569784

Robbins, S. P., \& Judge, T. A. (2015). Perilaku Organisasi Organizational Behavior 16/E (R. Saraswati \& F. Sirait (Eds.); 16th ed.). Salemba Empat.

Setiawan, H., Minarsih, M. M., \& Fathoni, A. (2016). Pengaruh Kualitas Produk, Kualitas Pelayanan Dan Kepercayaan Terhadap Kepuasan Nasabah Dan Loyalitas Nasabah Dengan Kepuasan Sebagai Variabel Intervening (Studi 
Kasus Pada Nasabah Koperasi Rejo Agung Sukses Cabang Ngaliyan). Journal of Management, 2(2).

Siddiqi, K. O. (2011). Interrelations between service quality attributes, customer satisfaction and customer loyalty in the retail banking sector in Bangladesh. International Journal of Business and Management, 6(3), 12-36.

Soegoto, A. S. (2013). Persepsi nilai dan kepercayaan terhadap kepuasan dan dampaknya terhadap loyalitas konsumen. Jurnal EMBA: Jurnal Riset Ekonomi, Manajemen, Bisnis Dan Akuntansi, 1(3), 1271-1283.

Soelistya, D., \& Agustina, H. (2017). Analisis Teknologi Informasi Mobile Banking Dan Persepsi Risiko Transaksi Terhadap Kepuasan Nasabah (Studi Kasus Bank Mandiri Syariah Cabang Jemur Handayani Surabaya ). Accounting and Management Journal, 1(2), 89-100.

Syafrullah, M. J., \& Wardhana, A. (2015). Pengaruh Kualitas Layanan Internet Banking Bank Mandiri Terhadap Kepuasan Nasabah Bank Mandiri Dengan Menggunakan Metode Webqual (studi Kasus Mahasiswa Telkom University). EProceedings of Management, 2(2).

Syahnur, M. H., Basalamah, J., \& Gani, A. A. (2020). Customer Experience Factor Analysis Towards Customer Satisfaction Online Shopping. Jurnal Analisis Bisnis Ekonomi, 18(2), 83-94.

Syahnur, M. H., Soeharijanto, M., \& Tazlie, L. (2018). Analisis Customer Experience Dengan Importance Performance Analysis (IPA) - Suatu Studi Pada Pelanggan Telkom Indihome. 5(2), 1-12.

Tjiptono, F. (2000). Prespektif Manajemen dan Pemasaran Kontemporer. Andi.

Tjiptono, F., \& Chandra., G. (2011). Service, Quality and Satisfaction (3rd ed.). Andi. Utami, S. (2015). The influence of customers' trust on customer loyalty. International Journal of Economics, Commerce and Management United Kingdom, 3(7), 638-653.

Wijaya, V. S., \& Wismantoro, Y. (2017). Pengaruh Kualitas Produk Dan Persepsi Harga Terhadap Kepuasan Nasabah Melalui Kepercayaan Nasabah Asuransi Jiwasraya Cabang Kudus. Jurnal Penelitian Ekonomi Dan Bisnis, 2(2), 101-113.

Yuliaty, T. (2014). Pengaruh Kualitas Layanan Internet Banking Dan Brand Equity Terhadap Kepuasan Nasabah Pada PT. Bank Syariah Mandiri Kcp Medan Aksara. JURNAL MANAJEMEN \& BISNIS, 14(02), 120-126.

Zeithaml, V., \& Bitner, M. (2008). Service Marketing. McGraw Hill Companies, Inc. 